Meta

Journal des traducteurs

Translators' Journal

\title{
Introduction: Looking Back
}

\section{Patricia Claxton}

Volume 45, numéro 1, avril 2000

La traduction littéraire au Canada

Literary Translation in Canada

URI : https://id.erudit.org/iderudit/002339ar

DOI : https://doi.org/10.7202/002339ar

Aller au sommaire du numéro

Éditeur(s)

Les Presses de l'Université de Montréal

ISSN

0026-0452 (imprimé)

1492-1421 (numérique)

Découvrir la revue

\section{Citer cet article}

Claxton, P. (2000). Introduction: Looking Back. Meta, 45(1), 7-12.

https://doi.org/10.7202/002339ar

\section{Résumé de l'article}

Bref historique de l'ATTLC / LTAC, mettant en particulier l'accent sur ses débuts difficiles.Activités limitées de l'époque comparativement à la diversité d'aujourd'hui. Coup d'œil vers l'avenir. Rappel des noms clés et remerciements. Dédicace.
Ce document est protégé par la loi sur le droit d'auteur. L'utilisation des services d’Érudit (y compris la reproduction) est assujettie à sa politique d'utilisation que vous pouvez consulter en ligne.

https://apropos.erudit.org/fr/usagers/politique-dutilisation/ 


\title{
Introduction: Looking Back
}

\author{
PATRICIA CLAXTON \\ Independent literary translator, first president of \\ l'Association des traducteurs et traductrices littéraires \\ du Canada / Literary Translators' Association of Canada
}

\section{RÉSUMÉ}

Bref historique de l'ATTLC / LTAC, mettant en particulier l'accent sur ses débuts difficiles. Activités limitées de l'époque comparativement à la diversité d'aujourd'hui. Coup d'œil vers l'avenir. Rappel des noms clés et remerciements. Dédicace.

\begin{abstract}
A brief historical overview of the ATTLC / LTAC, with emphasis on the very beginnings. Comparison between the limited range of activities then and the abundance now. $A$ glance forward. Recall of key names and thanks. Dedication.

\section{MOTS-CLÉS/KEYWORDS}

Literary Translators' Association of Canada (LTAC) / Association des traducteurs littéraires du Canada (ATTLC), Canadian Copyright Act, literary translation in Canada
\end{abstract}

A twenty-fifth anniversary is a time for celebration. Also a time for remembrance and sober reflexion.

The Literary Translators' Association of Canada was born on Saturday, May 17, 1975 at 2:30 in the afternoon when, as recorded in the minutes taken by Pierre Nepveu, Philip Stratford moved that L'Association des traducteurs littéraires existe maintenant (14:30) de fait and the motion was adopté à l'unanimité. The words "du Canada / of Canada" were added to the name at the time of the Association's incorporation in 1997.

The birth released some heady elation. Yet it was not universally welcomed. Certain Quebec professional translator's circles, having succeeded in unifying disparate groups, regarded our initiative as a betrayal, not knowing how strongly those of us who were already members of those circles had in fact advocated an affiliation with them. At the time not understanding either the reasoning behind our decision to stand alone in that the major problems and preoccupations of literary translators are so much more akin to those of writers than to those of most other translators. Also in that our sister associations were all provincial in scope whereas our membership was bound to be spread across the country. Generally speaking, publishers were also unenthusiastic. Still, Jack McClelland did accept our invitation to address our founding convention, guardedly telling us that we could perform a useful function, and answering questions from the floor. It took many years for us to persuade most of our publishers, French and English, that as a group we were allies, not antagonists.

We were heartened, on the other hand, to be greeted warmly by writers and by translator groups in France, Britain and the United States. L'Union des écrivains québécois had not yet been created (would appear very shortly after our creation) but, despite publishers' ombrous warnings that we were bent on siphoning off even 
more of our writers' already meagre earnings, The Writers'Union of Canada was extremely supportive. Its president, Andreas Schroeder, gave us a great deal of advice and attended both our founding meeting and our second general meeting. In our planning stages we had corresponded with the French, British and American translator groups and subsequently continued to consult and exchange information with them and a German group. Charles Parsons, president of the Guild of Professional Translators in the United States, came to our second general meeting as a guest and resource person (to my knowledge, the American Literary Translators' Association was not yet in existence).

The proposal to deliberate the creation of our Association was issued by the Stanley House Group, a gathering of fourteen people at a seminar, organized by Philip Stratford, at Stanley House, a property then owned and operated by the Canada Council for cultural conferences, located at Richmond, Quebec, on the Gaspé Peninsula by the Baie des Chaleurs. Attending this seminar were twelve translators, a French-language publisher, and a representative of the Canada Council. A representative of the Toronto publishing community was expected to attend but never arrived. The names of the members of the Stanley House Group are listed toward the end of this article.

Most of the Stanley House Group met as strangers but all, French-speaking and English-speaking alike, quickly discovered common ground to an astonishing degree in shared concerns, satisfactions, and frustrations in their work. The major outcome of the conference was a decision that the literary translators of the country needed to band together for the benefit of both literary translation and literary translators, and that in a year's time a convention should be held at which the Group would propose the formation of an association of literary translators.

The preparation of this convention fell to Philip Stratford and me. Following instructions from the Group, we sent out invitations as widely as possible, making it clear that this was to be a professional association, not a social circle. We sought translators working in any language combinations, realizing however that most would be working between French and English.

The convention was held at the Bonaventure Hotel in Montreal on Friday and Saturday, May 16 and 17, 1975. To provide a point of departure for the discussions, we had prepared a draft constitution. It was a very simple document, which was just as well because there was vigorous debate over two aspects of the most basic question, eligibility for membership. First, whether membership should be tied to Canadian citizenship or residency or eligibility for Canada Council grants, or whether there should be no such restriction whatever. Second, an equally thorny point, how literary should "literary" be deemed to be, or what kind of translation, and how many, should be required for a translator to be eligible to become a member, and then remain one. We may marvel today that such picayune things took up so much time, but when a body is being created from nothing, small things once cast in stone can become millstones if decided wrong in haste. Although they may look small in hindsight, the time it takes to have them well aired and carefully considered by all concerned is not wasted. The rest of the constitution was settled with relative calm, and then, in response to Phil Stratford's motion, on Saturday afternoon the Association was voted into existence, the articles of the Constitution were adopted one by one with the amendments agreed on earlier, and the meeting proceeded to set a three-level scale 
of fees, then to the election of the executive. The most natural and obvious choice for founding president, in my mind and surely in the minds of many others, was Phil Stratford, and I had been comfortably confident that this was the way our small world would unfold. But Phil had another idea. No, he said, he was going to propose me as president, although he would agree to be secretary so that we could continue to work as a team. I do not remember at what moment exactly I learned of this, but once my initial alarm had abated, the normal course of things resumed.

In the first two years, as the members wished, a great deal of work was devoted to developing a model agreement and guide, which were studied at each general meeting. Correspondence was exchanged with British, French and American literary translators' associations to this effect, and an interesting German model was obtained as well. At the earliest stage, the agreement was to be viewed as based on the "humblest member" principle, that is, what we would insist on as being the right of the humblest member, an official base line, something we would not compromise on. As the agreement evolved, the guide became more comprehensive and explanatory in order to inform publishers and the public as well as members. Eventually the agreement came to resemble the model agreement of The Writers' Union of Canada, partly to present our contracting parties with a document having familiar features to a degree. At this stage, UNEQ was also taking some cues from TWUC on these matters.

Working conditions and treatment of members by those using their services were a real concern. Questionnaires were circulated and the replies analyzed. It became imperative to learn exactly where literary translators' rights lay. At annual meetings and others in between we listened to many tales of woe from members, and in a couple of instances engaged a lawyer to handle their cases, and helped pay the fees. On the other hand, one of our objectives since the beginning had been to improve the image of literary translators with the public and the press. As early as the second general meeting, a question was raised about the multiple proficiencies claimed in the membership list by many members, that is, translation in two directions or in several languages. It was felt that the Association should endorse only proven abilities, and that the listing of languages and direction of translation should be limited to those in which a member had done major work.

An early initiative was the adoption of a watchdog role for the Association, scrutinizing reviews of translations and notifying editors of newspapers and magazines when translators were not properly acknowledged. Plus ça change...!

At this early stage also, consideration was given to the creation of a mediation committee to adjudicate disputes with contracting parties over quality of work. The procedure was later put into effect, was resorted to several times and, I believe, earned respect for the Association.

In 1977, the third year of its existence, the Association participated in a major event, the Eighth World Congress of the Fédération Internationale des Traducteurs (FIT), which was held in Montreal, with several members presenting papers. This was made possible by the Association's membership in the umbrella Canadian association CTIC (Canadian Translators and Interpretors Council), since only national associations could be FIT members, and at the time ours could not afford its own membership in the FIT.

Beginning in 1977, we were caught up in the revision of the Canadian Copyright Act, for which we were poorly prepared. However, this tied in with our need to know 
our rights as literary translators. Two enterprising officials of the Quebec government's Bureau de la Propriété intellectuelle undertook to coach Quebec creators' associations on copyright with a view to helping us out of a morass of confusion over how to present cogent briefs on the proposed revision. In the existing Act dating back to 1928, there was no mention of translations, but we discovered British and Canadian jurisprudence and relevent authorial comment establishing clearly that translations were already recognized as literary works subject to the protection of copyright law. From that point on, we pursued the goal of having translations expressly mentioned as literary works in the Canadian Copyright Act. We submitted three briefs to this effect, together with some other arguments, between 1978 and 1985, and appeared before a parliamentary committee in 1985. Against bland assurances and seemingly stolid indifference on the part of departmental officials, after dogged hammering and appeals to the minister, Hon. Flora Macdonald, at the third (and last) reading translations finally appeared in the definition of literary works in the draft law, and then in the revised Act as passed on December 11, 1987. A victory.

The Association can claim other victories for translators in general. In Public Lending Rights, our representative fought for and won a 50/50 split of rights payments with authors. We have not for a long time heard of refusal to put a translator's name on the flypage of a book or in the credits for a film or play, etc.; many publishers, in English Canada at least, now agree without argument to put a translator's name on the cover of the dust jacket of a book. Usually, although still not always, the translator is at least mentioned when a translation is reviewed or discussed. This is not just a courtesy but a legal right which, we now realize, we face a continuing battle to have recognized.

In the early years we had no operating grant money at all; the only funding we received from government was to enable geographically distant members to travel to annual general meetings. We did what we could with what little we had, even producing a modest newsletter, but I only need to turn the pages of Transmission, our present newsletter, to realize how little we did compared to all we do now, even though now once again we are reduced to nothing but our membership fees, short of endlessly scaring up special grants for this project and that, or just to keep some longstanding operation going; a harrowing business, especially for the president. Nevertheless, the Association is represented regularly at conventions and conferences at home and abroad, and is an active participant in the organization and realization of many events such as the soirées littéraires "Assonance" and "Dissonance" on International Translation Day, September 30, 1998 and 1999 (the first in conjunction with OTIAQ), Métropolis bleu / Blue Metropolis in conjunction with the Quebec Writers' Federation and UNEQ in April 1999, a number of events over the years at book fairs across Canada, and Word On the Street events in Toronto, Ottawa, Calgary, Vancouver and Halifax. It organizes its own regular activities like the annual John Glassco Prize and the Phil Stratford Readings, and publishes periodically a catalogue of its members' works in translation for the use of librarians, publishers and booksellers, as well as, three times a year, its newsletter Transmission. In conjunction with the Association of Translators and Interpreters of Alberta, it has collaborated in the publication of four successive volumes of the journal TransLit, consisting of translated poems and prose selections together with the original texts. It honours distinguished members from time to time with the publication of a special volume of 
work, the first of these being a book of stories by Joyce Marshall, translated by fellow members, Blood and Bone / En chair et en os (Toronto: Mosaic Press, 1995).

Having looked back, we should not forget to turn around and look forward. As we begin our second quarter century, we will need to protect the ground we have gained as a profession. Perhaps we can gain some more, particularly in some sectors. The Association exists primarily for this, both directly and through the recognition it promotes with many of its activities. But the Association lives and achieves because it is made of individuals who believe that the time they give and the efforts they devote freely and generously lead to something good for all, and that what they get out of it is commensurate with what they put in. It will continue to live and achieve as long its membership counts people who believe they are doing something of worth together.

Members who have given many hours year in and year out to the Association crowd into my memory. Some compose the faithful little core group still active, some have left this world, some have moved to occupations that exclude continued activity, and some, inevitably in the space of twenty-five years, we no longer see. Some have more recently joined the active core group. Besides Phil Stratford, they include Phyllis Aronoff, Michelle Asselin, Ed Barsamian, Betty Bednarski, Jean-Antonin Billard, Gérard Boulad, Marie-Cécile Brasseur, Ray Chamberlain, Marie-Andrée Clermont, Nicole Ferron, Hélène Filion, Patricia Godbout, Christine Klein-Lataud, Nésida Loyer, Joyce Marshall, Suzanne Mineau, Frances Morgan, Lou Nelson, Susan Ouriou, Jean Paré, Jean-Paul Partensky, Francine Pominville, Jean Simard, Agnes Whitfield, Louise von Flotow. These do not include presidents, several of whom have remained active after their terms in office, which are always extremely demanding.

The presidents with their years in office are as follows:

$\begin{array}{lll}\text { Patricia Claxton } & 1975 & -1979 \\ \text { Michel Beaulieu } & \text { May } 1979 & - \text { Sept. } 1979 \\ \text { Ray Ellenwood } & \text { Sept. 1979 } & - \text { June } 1983 \\ \text { David Homel } & 1983 & -1986 \\ \text { Robert Paquin } & 1986 & -1988 \\ \text { Sherry Simon \& } & & \\ \text { Michel Buttiens (co-presidents) } & 1988 & -1990 \\ \text { Jane Brierley } & 1990 & -1994 \\ \text { Beatriz Zeller } & 1994 & -1997 \\ \text { Charlotte Melançon } & 1997 & -1999 \\ \text { Howard Scott } & 1999 & -\end{array}$

Finally, the Stanley House Group, those who started it all, were:

Betty Bednarski
Alan Brown
Michael Bullock
Patricia Claxton
Sheila Fischman
Naïm Kattan (Canada Council rep.)
Joyce Marshall

\author{
Pierre Nepveu \\ Jean Paré \\ Larry Shouldice \\ Jean Simard \\ Philip Stratford \\ Michelle Tisseyre \\ Pierre Tisseyre (publisher)
}

To all these people I have named, and some I have not, and I hope they will forgive me, thank you on behalf of the Association for your contribution to the advancement of the quality and profession of literary translation chez nous, as well as 
for the vigour you have infused into the Association. And a personal thank you from me for so much enrichment and friendship.

As planned, this introduction would have been written by Philip Stratford. He was more qualified than I for the task, by all measures. I am honoured to be writing it in his stead, without for a minute imagining that my words might replace the graceful prose that he would have penned.

As for his relationship to the ATTLC / LTAC, I once heard him describe himself as having been midwife to the organization. Yet the metaphor is not really fair, for Phil did not pack up his paraphernalia and leave after the birth, as midwives do, but continued to toil over the child and care for it, as a loving parent would. Before the blessed event, he worked to organize the Stanley House conference, then the founding convention of the Association, with me assisting, and then, postpartum, for a further two years as secretary during my first term as president. He was involved in almost everything during this time, for there were still no patterns laid down and we were groping our way, with new and unexpected challenges falling upon us, as thick as rain it seemed sometimes. After this period, he was always generous with his help, always there at our gatherings, always informed about what was going on, always ready with opinions and wise advice, always present among us with his twinkling eye and his laughter. This special issue of Meta commemorating the twenty-fifth anniversary of the Association des traducteurs et traductrices littéraires du Canada / Literary Translators' Association of Canada is dedicated to Phil Stratford with affection and gratitude.

The Association wishes also to express sincere thanks to André Clas and the Editorial Board of Meta for so kindly making this special issue possible.

This is one of the important ways in which we are proudly celebrating our first quarter century. 